\title{
The Anthropocene and the Technogene: stratigraphic temporal implications of the geological action of humankind
}

\section{O Antropoceno e o Tecnógeno: implicações geocronológicas da ação geológica da humanidade}

\author{
Antonio Manoel dos Santos Oliveira ${ }^{\text {ac }}$, Alex Ubiratan Goossens Peloggia ${ }^{\text {bd }}$

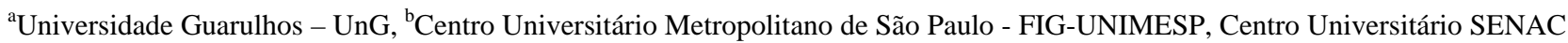 \\ e Faculdade SENAI de Tecnologia Ambiental \\ caoliveira@prof.ung.br, dalex.ugpeloggia@uol.com.br
}

\begin{abstract}
During the last years some original ideas concerning the geochronologic implications of human geological activities have been proposed, such as the Technogene and Anthropocene concepts as new geological periods. The essential aspects of the issue are the magnitude and frequency of these activities, the extent and significance of their correlative geological records and, of course, the nature of the stratigraphic time-related classification itself. In this paper we propose an alternative solution, which takes into account diachronic units (namely geotechnogenic events and phases) as appropriated for classifying the products of geological human action during the Quaternary.
\end{abstract}

Keywords: Anthropocene; Technogene; Geotechnogenic Diachronic Units.

\section{RESUMO}

Ao longo dos últimos anos algumas ideias originais relativas às implicações geocronológicas das atividades geológicas do Homem tem sido propostas, como os conceitos do Tecnógeno e do Antropoceno como novos períodos geológicos. Os pontos essenciais da questão referem-se à magnitude e à frequência dessas atividades, a extensão e significância de seus registros geológicos correlativos e, certamente, a própria natureza da classificação estratigráfica do tempo geológico. Neste trabalho propomos uma solução alternativa, que implica na consideração de unidades diacrônicas (especificamente eventos e fases geotecnogênicas) para englobar os produtos da ação geológica do Homem duante o Quaternário.

Palavras-chave: Antropoceno; Tecnógeno; Unidades Diacrônicas Geotecnogênicas.

\section{Introduction}

The problems related to the geochronologic position on the human action correlative geological records, namely the technogenic or anthropogenic deposits and the artificial ground, centres around some contemporary questions asked concerning the proposition of a new geologic time scale. The discussions have reached widespread international relevance in particular after the proposition, by Crutzen \& Stoermer (2000) and Crutzen (2002 a,b), on the Antropocene concept. The broad interest for this issue may be evaluated by its repercussion in the press, for example during 2011 appearing in large circulation publications such as The Economist ${ }^{1}$ and National Geographic ${ }^{2}$, amongst others. However, it is a theme in which brazilian research may contribute significantly

\footnotetext{
1 "Welcome to the Anthropocene", may 26th, 2011. www.economist.com.

2 “Age of Man”, march 2011, ngm.nationalgeographic.com.
}

as knowledge on the category of geological materials has been accumulated since the 1990's (Oliveira el al. 2005).

The subject of this paper is the discussion of the contemporary situation of the stratigraphic question concerning a new Quaternary geological time scale or, in other words, the stratigraphic statute of human action in geological records. This issue is enhanced by the proposal of an alternative stratigraphic approach that expands the scope of these records as diachronic units (presented by events and phases) in the sense as defined by the 1983's North American Stratigraphic Code, and in the production of a geotechnogenic time table based on these principles.

\section{Humankind as a geological agent.}

The understanding of humankind's geological and geomorphologic role isn't new. One of the first literary references on this action was cited by Charles Lyell in his Principles of Geology, is Dante's Inferno. Specific geological references to human induced sedimentary 
Antropoceno - Tecnógeno

deposits were made by Eschwege in the late 1700's (gold placer mining river deposits from Minas Gerais, Brazil) and by Suess in the 1800's (Viena's made ground) (see Peloggia 2005, for a synthesis). Lyell himself, in the book The Geological Evidences of the Antiquity of Man presents what is certainly one of the early (perhaps the first) "technogenic geological" sections in which the made ground is represented. Branner (1906), on the item "Man as a geological agent" in his book Geologia Elementar refers to "typical deposits" formed by city waste dumping.

However, the classical work concerning specifically and systematically the geological action of humankind is due mainly to Sherlock (1922). This author wrote a bibliographic revision of previous works dealing with the subject of human geological agency, citing for example: G.P. Marsh's The Earth as modified by Human Action, in which "the geological aspect of Man's work is but briefly considered”; A. Geikies' Text-Book of Geology, in which only three pages are devoted to a brief outline of the subject, compared with T.C. Chamberlain and R.D. Salisbury's Geology in which they devote less than two pages to "Man as a geological agent”.

Nevertheless, in the late 1900's, some new conceptions on the geological action of humankind had been proposed by soviet researchers, such as the Anthropogene (Gerasimov 1979) and technogenic deposits (Chemekov 1983). Meanwhile, the latest and detailed proposal was written by Ter-Stepanian (1983, 1988, 1994): the Quinary or Technogene period.

It must be highlighted that the conceptions concerning the human geological action and technogenic deposits have had great repercussions and received acceptance in Brazil, since the early 1990's, among Engineering Geology and Physical Geography professionals and researchers (see Oliveira et al. 2005 for a synthesis). This has been due to the development of the Geotechnogenic Approach (Oliveira, 1990) and the Technogene Geology conception (Peloggia 1998a), which methodologically including the integrated study of processes, morphogenesis and deposits related to the activity of humankind, as well as including the concepts of antropostrome (Paserini 1984) and lithologic effectuation (Rohde 1996).

Since the middle 1990's, a significant number of papers has been published, in the geological and geomorphologic international literature, in particular by North American and British researchers, remarking on the importance of the human influence on the geological processes and discussing its geochronologic consequences (e.g. Goudie 1993, 1994, Hooke 1994, 1999, 2000, Waltham \& Forster 1999, Wilkinson 2005). The event that has had more repercussions was the publication, in the early 2000's, of the Antropocene concept by Crutzen \& Stoermer (2000) and Crutzen (2002 a,b). This conception was developed independently of the theory of the Technogene and, in many points, repeats some questions already discussed (Crutzen \& Steffen 2003, Steffen et al. 2007,
Zalasiewics et al. 2008, Steffen et al. 2011, Zalasiewics et al. 2010, Zalasiewics et al. 2011 a,b).

\section{The Quaternary period and the rise of humankind.}

Modern humans have in fact appeared during Quaternary (Pleistocene) times and his influence on the geological processes, of course, must be regarded as a progressive possibility to change quaternary processes and to transform quaternary landscapes. If we take this into account, it will be possible to understand that, if the geological action of humankind is considered - as it really should be - a new and differentiated situation in Earth's history exists. Consequences and records must dialectically acknowledge it, as a "revolutionary period" (catastrophic, because of the intensification of processes) and as a "jump" (in function of the creation of new processes) in Earth's history (Peloggia 1998b), but also as a progressive continuity.

In other words: humans as geological agents existed during Quaternary times and have altered the age, but it remains known as "Quaternary Man", because the Earth surface inherited by humankind consisted of Quaternary landscapes formed by quaternary ground. Meanwhile, it is certain too that humans have transformed extensively the former landscapes and created several new ground types, by producing technogenic (artificial) deposits that configures new technogenic landforms.

So, the relationship between the Quaternary, specifically the Holocene, geological processes, deposits and landscapes, and the new technogenic ones, must be clearly understood as a base to understanding the meaning of the results of Man's geological agency itself and the geochronologic and stratigraphic consequences. The main tendencies of thinking concerning this subject have different points of view about the relationship between the Holocene and the new geological epoch now rising, as it will be detailed later. Nevertheless, it will be sufficient now to assume that the main positions (related to the Technogene and to the Anthropocene proposals) consider this new "epoch" in geochronologic terms. The opinion of this paper is that the issue can be better discussed by inserting a new perspective expressed by the use of another type of time related stratigraphic category: the Diachronic age

\section{Former geochronologic proposals}

\subsection{The Antropogene, the Psychozoic and the Noozoic}

Allègre (1993) introduced the neologism Noozoic to indicate the geological period in that believing animals (that is, humans) emerge and become a geological agent. Remarks that the progressive key in the geological role played by man is placed into the Quaternary complex superficial system, in which the essential geological agent is water, the geological process energy sources are the Sun and gravity and that the climate is changed considerably. The author 
considers the modifications made by humankind through Earth's planetary layers, (the atmosphere, the hydrosphere and the lithosphere), particularly in what concerns the qualitative, modification or erosion processes to be where Man's specific geological agency takes place. In all, the author considers that anything taking place between these periods Quaternary and Noozoic, it will be necessary to use both terms.

Be as it may, it is clear that the theoretical foundations for the Noozoic concept as proposed by Allègre can be found in the Teilhard de Chardin's (1955) reasoning about human's place and role in Earth's history. The author thinks in terms of successive processes: Geogenesis, Biogenesis, Psychogenesis (that lead to Man) and finally the Noogenesis, also a neologism used to designate the rise of the ultimate human advanced forms of psyche and consciousness. In all these "phases", each one we can understand as having ontologically priority to the next, in this way producing specific "spheres" or layers (as defined by Suess, Lithosphere, Hydrosphere and Atmosphere) and adding to each layer of the living things in the Biosphere in turn with the last sphere emerging finally from the Noosphere, the "thinking layer" of the planet. Chardin adopts the term Psychozoic created by Joseph LeConte (1823 - 1901) to refer to this new geological era.

In this context, it is interesting to remark that the use of Man's rise from the natural world as a criterion to define a new geological time unit was used just by Lyell in his proposals for the Pleistocene or PostTertiary (Lyell 2004 [1863], Lyell 1867), despite Lyell's focus had been the human fossilized remains and not the ability of human thinking.

\subsection{The Technogene and the Quinary}

Ter Stepanian (1988, p.134) considers that "human influence as a geological agent during the time before the Holocene period was comparable and fundamentally not different from the action of other living creatures", but not taking into account two essential differences concerning human being: the increasing use of tools and more significantly, the use of extra-somatic energy, namely fire. For the author, the situation only changed after the transition to agriculture and cattle-breeding, that is the beginning of the food production process, namely the Childe's Neolithic Revolution.

For these reasons, Ter Stepanian (1988) considers the Holocene as "the transition epoch from the Quaternary or the Pleistocene to the Quinary or the Technogene”. The conception is clearly diachronic: during the Holocene, restricted "Quinary districts of human influence" have been formed and increased on "the common "Quaternary background". These districts merged together and have turned into progressively vast regions.

Finally, the author defends the notion that the Holocene "should be classed with the Quinary or the
Technogene" periods, since the beginning of the transition epoch corresponds to a "outright Quaternary situation", while its end "will be marked by a being out rightly Quinary”. In this way, it can be understood that Ter Stepanian's geochronologic proposal considers the Technogene as the establishment of a new geological period, and that we are living now in a transition epoch progressively more dominated by technogenic situations, as viewed in the figure 1.

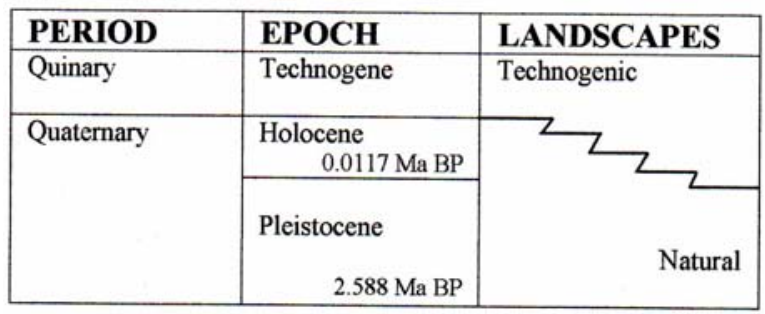

Figure 1: Interpretation of Ter Stepanian's geochronologic proposal (adapted from Oliveira et al. 2005; ages according to International Commission on Stratigraphy/International Chronostratigraphic Chart v2013/01)

\subsection{The Anthropocene}

Crutzen \& Stoermer (2000) and Crutzen (2000a,b) have proposed the term Anthropocene and has argued that the term has been justified and appropriated for its use to be assigned to the current human-dominated geological epoch (or even "era”) in which human activities have grown to become "significant geological forces” through land use changes, deforestation, fossil fuel burning and other "increasing impacts on the environment on all scales". Nevertheless, Crutzen (2000a) has cited previous works concerning human geological influence on the environment, such as the Italian geologist Stopani's reference to the “anthropozoic era” and Vernadsky and Chardin's use of the term "noosphere"

For Crutzen (2000a), the Anthropocene can be considered as having started in the late 1700's, for when the air trapped in the polar ice samples shows the initial increase of the global carbon dioxide and methane concentration rates. In fact, the main parameter proposed, according to this point of view, was to define that the Anthopocene, was consolidated as the atmospheric carbon dioxide concentration increased. Afterwards this was used to mark the beginning of the new epoch around 1800 ad, and relate it to the industrialization process (Steffen et al. 2007). The reasoning is quite simple: in influencing the atmosphere, Man's action has turned global.

Zelasiewicz et al. (2008) proposed the consideration of the Anthropocene as a formal epoch, starting during the Industrial Revolution and having endured sufficient changes (biotical, sedimentary and chemical) to leave a global stratigraphic signature distinct from that of the Holocene or even the Pleistocene interglacial phases. The proposal is argued on the basis of human influence on climate, environment, sedimentation, temperature, biotic and ocean changes. 
Antropoceno - Tecnógeno

\section{A new perspective on the Quaternary time scale}

\subsection{The stratigraphic approach}

As it's known, the stratigraphic classification deals with the systematic organization of Earth's strata into units defined by certain criteria (i.e., properties or attributes of the geological layers, such as lithology, fossil content or age of deposition), and as technogenic deposits considered as geological superficial formations (like the alluvium), they must be stratigraphically classified in a formal way (Peloggia 2003). Zalasiewicz et al. (2011b) also propose the idea of anthropogenic geological records using stratigraphic criteria (lithostratigraphic, chemostratigraphic and biostratigraphic).

This issue is quite clear in that it concerns technogenic sedimentary deposits, which can be considered as, for example, alloformations, such as the Resgate Alloformation (an alluvium-like technogenic sedimentary deposit), the Carrapato Alloformation (a colluvium-like sedimentary deposit), as defined in the slopes and valley flats of Paraíba do Sul River Valley in southeast Brazil (Moura \& Mello1991, Mello et al. 1995, Mello 1977, Ribeiro et al. 1996), or the Ribeirão Mombaça Alloformation, proposed by Mello (1997). These deposits, like many others of the same type, in fact can supply to the geologist all the requisites required to formally classify: internal characteristics, boundaries, map ability, locality and extent; geomorphic surfaces and extension (NACSM 1983).

These formations are correlative records of land use modification, in particular representing landscape "physiologic disturbs" that lead to accelerated erosion processes and unusually high rates of immature sedimentation. Nevertheless, these man-induced geological events are not, as indicated by clearly identified boundary surfaces associated with the deposits (sometimes classified as unconformities), merely more by the sequence of erosion-deposition episodes occurred during Quaternary or, in particular, Holocene times.

Despite the rates of accumulation and frequency of occurrence of this kind of technogenic deposit over former quaternary deposits or natural soil horizons, and the accelerated erosion and deposition processes that had took place over the quaternary landscape, the human influence over the land surface and the natural ground is itself an event of distinct qualitative character than the Holocene natural processes themselves (Peloggia 2003). The analysis of the particularity of human geological action has been considered by many authors, as cited above in this paper.

Meanwhile, the allostratigraphic classification, as proposed by the 1983's North American Stratigraphic Code (NACSN 1983), doesn't consider the geological history and the age as adequate parameters for the definition of alloformations (or other allostratigraphic units), only consideration for the facts as useful tools for the choice of formation's boundaries. This is similar to the lithostratigraphic classification. In conclusion, it is possible to affirm that sedimentary technogenic deposits can be classified as common stratigraphic units related to material content. The same reasoning can be applied to technogenic soil horizons, which may be classified as pedostratigraphic units.

However, it is possible, in a global sense, to defend that the technogenic built up deposits (including all the made ground) are also able to be receive the stratigraphic statute of geological records of human action. The question concerning the nature of this statute is already an open issue, since the positioning of these kind of deposits or layers in the formal stratigraphic classifications, as "formations" for example, in spite of former attempts (the Varzea do Carmo formation, a designation proposed by Peloggia, 1998 , to indicate the made ground that covers the former floodplains - today technogenic landscapes - in São Paulo City, Brazil), appears not to be the only solution.

Peloggia (2003) opines that the classification of technogenic deposits, and we can extend this opinion to include all the technogenic aggraded ground (sensu Peloggia et al. 2014), can not fail to take into account the genetic identification as a fundamental criterion to classify these particular geological records. The author proposes the discussion of an enhanced stratigraphic category concept that takes into account the genetic processes and geological history as being distinctive, because the lithologic distinction is not always possible.

In this context, we propose in this paper to use the Diachronic Units, as defined in the 1983's North American Stratigraphic Code, without bias of other possibilities, as the best form to confirm the geological correlative records of human action, indicated now as geotechnogenic units. Despite the time-related nature of the diachronic units, they depend on the existence of material registers (the technogenic deposits), and can be defined just where these records have been created throughout the world. We also argue that this conception is in principle sustainable taking into account the former considerations by Watson \& Wrigth (1980 apud Farrand 1990 p.21), who argue that "all Quaternary units are demonstrably diachronic and that our terminology and explanatory models should reflect this fact”.

The conception exposed above is compatible with the reasoning of Ter-Stepanian in which concerns the progressive and diachronic extension of "technogenic districts" during the Holocene, and also with the proposal of a globally differentiated geological situation established after the Industrial Revolution. For the stratigraphic time related classification of the geological records of these technogenic situations it is neither necessary to change the Geocronologic Scale, nor to abandon the Quaternary, considered in the same sense as Antropogene.

In this way, the technogenic layers are considered Quaternary diachronic units (geotechnogenic units), and are associated here, according to their ages, to two 
main stratigraphic events: the Pre-Technogene and the Technogene. The second event is, by its way, diachronically subdivided into the Antropocenic or Late Technogenic phase and the Pre-Anthropocenic or Early Technogenic phases.

In this context, the concept of technogenicgeochonologic stratigraphic units proposed here deals with the issues involved in the correlation between synchronous geological records produced by natural agents and that of mankind, since the geological action of humankind is relatively new in geological history. The "Geotechnogenic Time Scale" (Diachronic) criteria are based, for this reason, in an integrated setting of criterion as discussed below.

\subsection{Criteria for Diachronic Geotechnogenic Units definition}

The criteria used for this classification are essentially three: technologic innovation, use of energy and population growth. Both criteria are related amongst each other, and each geotechnogenic event or phase results from a combination in which their significance may varies. Taking into account the propositions discussed above, we define and outline the main characteristics of the following geotechnogenic diachronic units (figures 2 and 3).

\section{The Pre-technogenic Event}

Humans had become geomorphic agents around 400,000 years ago, making dwellings' walls and foundations with boulders and stone rubble (Hooke 2000). It is possible that several made ground produced as life-place technogenic deposits have been submerged (as a result of sea levels rising after the last Ice Age) or simply collapsed.

Meanwhile, the essential, first and most decisive occurrence of this phase is, aside the use of hand tools, the deliberate and regular use of fire as a form of extra-somatic energy (Boyden \& Hadley 1986). Its ecological impact on the frequency of forest and grass fires had an important role in changing landscapes (mainly plant cover) and logically, in consequence, erosion and sediment production rates. By deduction, it is possible to affirm that the first technogenic induced deposits certainly were created during these times.

Be as it may, human population has remained limited and settlement sparse until Neolithic times.

\section{The Technogenic event}

The so called Neolithic Revolution (Childe 1965) is the reference cited by Ter-Stepanian $(1988,1993)$ for the beginning of the transition to Technogene or Quinary. In geochronologic terms, it corresponds to the start of Holocene (after the last glaciation, around 10,000 years ago). This major technological and cultural episode is stated in this paper as the start of the diachronic Technogenic Event, due to its original geological and geomorphologic repercussion.

The Technogenic Event can be divided into transition phases to the contemporary phase, namely the
Anthropocene. According to Kowalski (1984), Neolithic farming revolution was the reason for the transformation of considerable parts of the natural geological environment, changed under the influence of human activities. The first phase of this event is just related to the agriculture development.

\section{The Agricultural Phase}

During these times, villages appeared and were constructed with sun-dried bricks (Hooke 2000), and of course the mud for bricks was excavated from natural deposits. These settlements were destroyed many times and had to be rebuilt usually on the same piece of ground, producing complex technogenic ground (archaeological or cultural layers). The demand for stones also increased leading to an increased amount of quarrying and underground mining. The effects of farming on geological conditions near river valleys and lowlands must be also considered despite the difficulty to recognise the amount of human influence (Kowalski 1984).

\section{The Urban phase}

Cities required water, and irrigation works that lead to large-scale earth-moving activities. Large earth or stone structures were constructed. The use of metallic tools (mainly iron, around 2,500 years ago) improved the human capacity for quarrying and the invention of the wheel (around 5,000 years ago) facilitated the transportation of geologic materials. Agriculture expanded, as well as the erosion rates (Hooke 2000). The irrigation activities produced great changes in water basins, and the smelting of metals, requiring great quantities of wood, must also resulted in significant deforestation.

\section{The Commercial Global Phase}

With the development of new navigation technologies, European explorers and traders began the still unfinished process of globalisation, by which new large areas of America, Africa and Asia were progressively incorporated into the new capitalist economies as production areas of agricultural commodities or mining products. These economical activities have impacted and transformed (mainly by deforesting), through the centuries, the original landscapes of the tropical world, resulting in great increase of erosion and production of technogenic induced sedimentary deposits, as in the Cuban case cited by Engels (1991) (see also Oliveira et al. 2005). The colonisation of new land, like the United States hinterland in the 1800's, as noted by Lyell (1867), produced analogue effects.

\section{The Anthropocenic (Industrial) phase}

The Anthropocenic phase designation derives from the word Anthropocene as proposed by Crutzen \& Stoermer (2000). This phase is marked essentially by an original combination of technological development and use of extra-somatic energy as never seen before. 
Antropoceno - Tecnógeno

With the industrial revolution, machinery began to be powered using energy converted from fuel, beginning with steam production. These machines increased in size and power and were used extensively during this period. This resulted in Man being a more effective geological agent in terms of frequency and magnitude.

During these times human-induced environmental changes have started a large scale biodiversity crisis (Leakey \& Lewin, 1997) and caused a large scale biogeochemical impact by causing natural cycles of new chemical compounds or remobilising vast amounts of substances before immobilised into the Earth's crust (Boyden \& Hadley 1986).

\section{Final Remarks}

Zelasiewicz et al. (2010) have received good reaction considering the previous concepts such as the Anthropozoic, Psychozoic and Noosphere had received "short shrift in the geological community". However, they compare directly with Crutzen's proposals concerning the Antropocene and its repercussions, but lack the impact of the Soviet school's Technogene concept, as well as other propositions like Allègre's Noozoic conception.
Voûte (1993, 2007), writing about Ter-Stepanian's Technogene proposal, highlights the role this conception plays as a tool for applied environmental geology at the service of the state and of the public, and affirms that Ter-Stepanian was in fact correct in considering that the advent of "Man the Maker" has indeed changed the course of evolution of the earth fundamentally.

In this context, Dorsh (2013), talking about the studies carried out by Edward Suess in the XIX century concerning the urban geology of Vienna (Austria), opines that the studies concerning technogenic deposits and cultural ground have played a role in the conceptions of the Anthropocene, the Anthropogene and the Technogene, which are considered by the author to be similar concepts.

However, Ter-Stepanian (1994) has considered the Technogene-Quinary, as a new geological period, differing clearly from all the others, including Quaternary. The Holocene, despite being too short in terms of geological time, is surprisingly different when considering large and quick environmental changes being found on the planet surface, in such an epoch of tectonic calm.

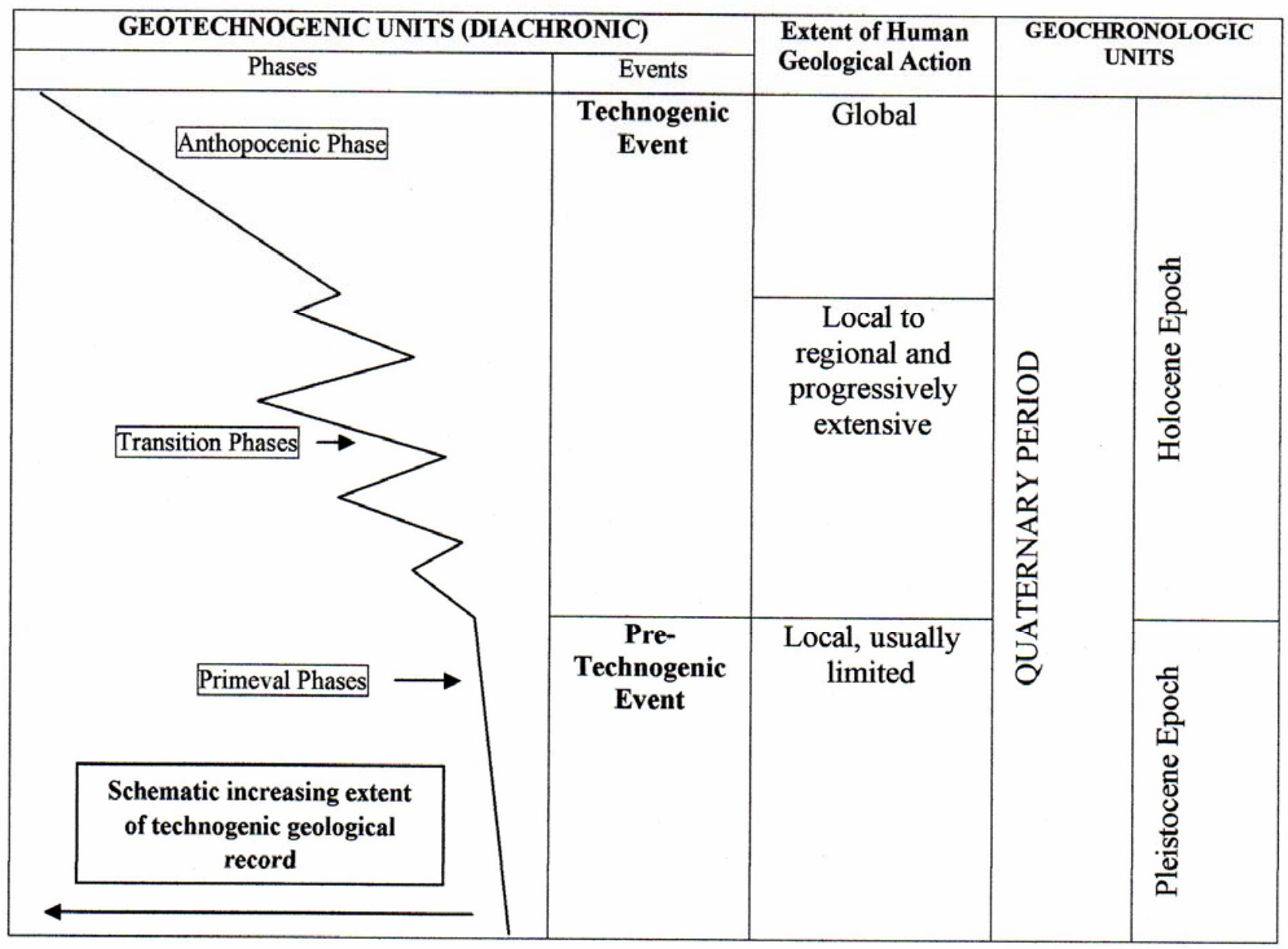

Figure 2: Schematic relations between Geotechnogenic diachronic units and the Quaternary. 


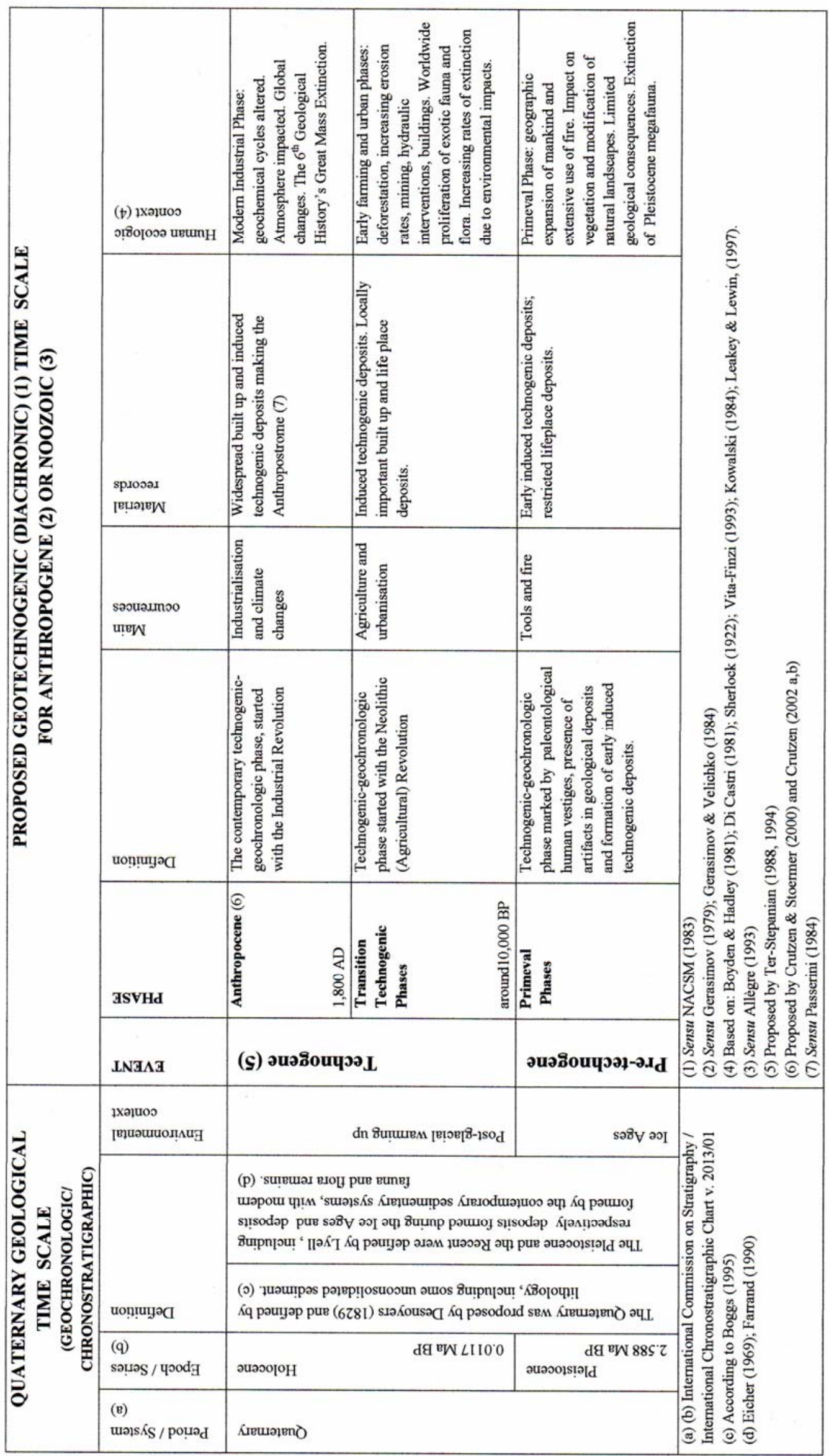

Figure 3: Proposed Geotechnogenic Time Scale. 
Antropoceno - Tecnógeno

The opinion proposed in this paper meets the other opinions half way. Consider humankind as an effective geological agent and that the geological records produced by his action must be formally considered in stratigraphic terms. They can be inserted in the Quaternary geological column as diachronic episodes and phases occurring during this time in specific technogenic regions that are increasingly widespread. This point of view is leaning towards the opinion stated by Gale \& Hoare (2013) in that the worldwide diachronic character of human impact makes it impossible to establish a single chronological datum for the Anthropocene or Technogene.

\section{Acknowledgments}

The authors are grateful to Mr. Brian Begley for his English linguistic support, and to an anonymous referee for terminological suggestions.

\section{References}

Allègre C. 1993. Introdução a uma História Natural: do Big Bang ao aparecimento do Homem. Teorema, Lisboa, 259p.

Boyden S., Hadley M. 1986. The Hand of Man. The Unesco Courier 1986:7, p.35-37.

Branner J.C. 1906. Geologia Elementar: preparada com referência especial aos estudantes brasileiros. Laemmert \& C, Rio de Janeiro, 306p.

Chardin P.T. 1955. Le Phénoméne Humain. Paris: Éditions du Seuil, 318p.

Chemekov Y.F. 1983. Technogenic deposits. In: INQUA Congress, 11, Moscow, Abstracts... v.3, p.62.

Childe V.G. 1965. Man Makes Himself. $4^{\text {th }}$ ed. Watts \& Co., London, 244p.

Crutzen P.J., Stoermer E.F. 2000. The Anthopocene. IGBP Newsletter 41: 17-18.

Crutzen P.J. 2002a. Geology of mankind. Nature 415(3): 23.

Crutzen P.J. 2002b. The "anthropocene". Journal de Physique, 12(10): $1-5$.

Crutzen P.J., Steffen W. 2003.. How long have we been in the Anthropocene Era? An editorial comment. Climate Change 61(3): 251-257.

Dorsch J. 2013. Eduard Suess, artificial ground, and the Anthropocene-Anthropogene-Technogene. 2013 GSA Annual Meeting, Denver (Colorado, USA). https:/gsa.confex.com/ gsa/ 2013AM/

Engels F. 1991 [1872-1882]. A Dialética da Natureza. 5.ed. Paz e Terra, Rio de Janeiro, 238p.

Farrand W.R. 1990. Origins of Quaternary-Pleistocene-Holocene stratigraphic terminology. In: Laporte L.F. (ed.), Establishment of a geologic framework for Paleoanthropology. Geological Society of America Special Paper 242, p.15-22.

Gale S.J., Hoare P.G. 2012. The stratigraphic status of the Anthropocene. The Holocene 22(12): 1491-1494.

Gerasimov I.P. 1979. Anthropogene and its major problem. Boreas 8(1): 23-30.

Goudie A. 1993. Human influence in geomorphology. Geomorphology 7: 37-59.

Goudie A. 1994. The human impact on the natural environment. $4^{\text {th }}$ ed. Cambridge: The MIT Press, 454p.

Hooke R.L. 1994. On the efficacy of humans as geomorphic agents. GSA Today 4(9)

Hooke R.L. 1999. Spatial distribution of human geomorphic activity in the United States: comparision with rivers. Earth Surface Processes and Landforms 24(8): 687-692.

Hooke R.L. 2000. On the history of humans as geomorphic agents. Geology 28(9): 843-846.

Leakey R., Lewin R. 1997. La Sixième Extinction: évolution et catasthophes. Paris: Flammarion, 352p.

Lyell C. 2004 [1863]. The Geological Evidence of the Antiquity of Man. Dover, Mineola (NY), 407p.
Lyell C. 1867. Principles of Geology. $10^{\text {th }}$ ed. John Murray, London, 463p.

Lyell C. 1997 [1830-33] Principles of Geology. Penguin, London, 472p.

Lyell C. 1871. The Student's Elements of Geology. London: John Murray, 640p.

Mello C.L., Moura J.R.S., Carmo I.O., Silva T.M., Peixoto M.N.O. 1995. Eventos de sedimentação durante o Holoceno no Médio Vale do Rio Paraíba do Sul (SP/RJ) - Aloestratigrafia e Datações por Radiocarbono. In: Congreso da Associação Brasileira de Estudos do Quaternário, V, Anais... ABEQUA/EDUFF, Niterói (RJ), p. 193-200. Available in: www.abequa.org.br/trabalhos/anais_1995.pdf. Accessed on the $24^{\text {th }}$ of September, 2013.

NASCM - North American Comission on Stratigraphic Nomenclature 1983. North American Stratigraphic Code. American Association of Petroleum Geologists Bulletin 67(5): 841-875.

Oliveira A.M.S. 1990. Depósitos tecnogênicos associados à erosão atual. In: Congresso Brasileiro de Geologia de Engenharia, 6, Salvador, ABGE, Atas... Salvador: ABGE, 1990, v.1: 411-415.

Oliveira A.M.S. 2005. Estudos sobre o Tecnógeno no Brasil. In: Congresso ABEQUA, 10, Guarapari, Anais... 2005. Available in: http://www.abequa.org.br. Accessed on the $24^{\text {th }}$ of September, 2013.

Oliveira A.M.S. 1995. A abordagem geotecnogênica: a Geologia de Engenharia no Quinário. In: Curso de Geologia aplicada ao meio ambiente - DIGEO/IPT. São Paulo: ABGE, p.231-241.

Oliveira A.M.S., Brannstrom C., Nolasco M., Peloggia A.U.G., Peixoto M.N.O., Coltrinari L. 2005. Tecnógeno: registros da ação geológica do homem. In: Souza C.R.G., Suguio K., Oliveira A.M.S., Oliveira P.E. (Eds.) Quaternário do Brasil, Ribeirão Preto (SP): Holos, Cap.17, p.363-378.

Passerini P. 1984. The ascent of the Anthropostrome: a point of view on the Man-Made Environment. Environmental Geology and Water Sciences 6(4): 211-221.

Peloggia A.U.G. 1998a. O Homem e o Ambiente Geológico: geologia, sociedade e ocupação urbana no Município de São Paulo. São Paulo: Xamã, 271p.

Peloggia A.U.G. 1998b. A magnitude e a frequência da ação humana representam uma ruptura na processualidade geológica na superfície terrestre? Geosul 14(27): 54-60 (Edição Especial: II Simpósio Nacional de Geomorfologia).

Peloggia A.U.G. 1999a. Sobre a classificação, enquadramento estratigráfico e cartografação dos solos e depósitos tecnogênicos. In: Peloggia A.U.G. (org.) Estudos de Geotécnica e Geologia Urbana (I). São Paulo: PMSP/SEHAB/HABI, p.35-50 (Manual Técnico 3 -GT-GEOTEC).

Peloggia A.U.G. 1999b. O Tecnógeno existe? In: Congresso Brasileiro de Geologia de Engenharia, 9, 1999, São Pedro (SP), Anais... São Pedro: ABGE (CD-ROM).

Peloggia A.U.G. 2003. O problema estratigráfico dos depósitos tecnogênicos. In: Congresso ABEQUA, 9, Recife, Anais Eletrônicos, 2003. Available in: http://www.abequa.org.br. Accessed on Sept. 22, 2013.

Peloggia A.U.G. 2005a. A ação geológica do homem nos clássicos da geologia, com especial atenção aos Principles of Geology de Lyell. In: Congresso ABEQUA, 10, 2005, Guarapari, Anais Eletrônicos... 2005. Available in: http://www.abequa.org.br. Accessed on the $24^{\text {th }}$ of September, 2013.

Peloggia A.U.G. 2005b. A cidade, as vertentes e as várzeas: a transformação do relevo pela ação do homem no município de São Paulo. Revista do Departamento de Geografia (FFLCHUSP) 16: 24-31.

Peloggia A.U.G., Oliveira A.M.S. 2005. Tecnógeno: um novo campo de estudos das geociências. In: Congresso ABEQUA, 10, 2005, Guarapari, Anais Eletrônicos... 2005. Available in: http://www.abequa.org.br. Accessed on the $24^{\text {th }}$ of September, 2013.

Peloggia A.U.G. 2012. Evolução dos conceitos estratigráficos relativos aos registros geológicos da ação humana. In: Congresso Brasileiro de Geologia,46.,2012, Santos (SP), Anais... SBG (CDROM).

Peloggia A.U.G. Oliveira A.M.S., Oliveira A.A., Silva E.C.N., Nunes J.O.R. 2014. Technogenic geodiversity: a proposal on the 
classification of artificial ground. Quaternary and Environmental Sciences (in press).

Rohde G.M. 1996. Epistemologia ambiental: uma abordagem filosófico-científica sobre a efetuação humana alopoiética. Porto Alegre: Edipucrs, 231p.

Sherlock R.L. 1922. Man as a geological agent: an account of his action on inanimate nature. London: H.F. \& G. Witherby, 372p.

Steffen W., Crutzen P.J., McNeill J.R. 2007. The Anthropocene: are humans now overwhelming the great forces of nature? AMBIO 36(8): 614-621.

Steffen W., Grinevald J., Crutzen P., McNeill J. 2011. The Anthropocene: conceptual and historical perspectives. Phil. Trans. R. Soc. A 369(1938): 842-867.

Ter-Stepanian G. 1983. Did the Quinary start? In: INQUA Congress, 11, Moscow, Abstracts... p.260.

Ter-Stepanian G. 1988. Beginning of the Technogene. Bulletin of the International Association of Engineering Geology, 38:133-142.

Ter-Stepanian, G. 1994. Beginning of a new period: the Technogene. Proceedings of the $29^{\text {th }}$ International Geological Congress, Kyoto(Japan), 1992. Part B: Quaternary Environmental Changes. Utrecht: VSP, 1994, p.299-308

Voûte C. 1993. First geologic map: an interesting contribution to applied geology. Environmental Geology 22: 286-288.

Voûte C. 2007. Lerning from Ancient Hydraulic Civilizations Eppawala: Heart of the Ancient Cultural Landscape of the Kalaweva - Jayaganga Ecosystem. In: Regional Pugwash Workshop in Honour of Jayantha Dhanapala President of the Pugwash Conference on Science and World Affairs 2007-2012, Sri Lanka, Proceedings... Sri Lanka Puwash Group, p.29-36.

Waltham T., Forster A. 1999. Man as geological agent. Geology Today 15(6):217-220.

Wilkinson B.H. 2005. Humans as geologic agents: a deep time perspective. Geology 33(3): 161-164.

Zalasiewicz J., Williams M., Smith A., Barry T.L., Coe A.L., Rawson P., Bown P.R., Cantrill D., Gale A., Gregory F.J., Hounslow M.W., Kerr A., Pearson P., Knox R., Powell J., Waters C., Marshall J., Oates M., Rawson P., Stone P. 2008. Are we now living in the Anthropocene? GSA Today 18(2): 4-8.

Zalasiewicz J., Williams M., Steffen W., Crutzen P. 2010. The New World of the Anthropocene. Environ. Sci. Technol. 44(7): 22282231.

Zalasiewicz J., Williams M., Haywood A., Ellis M. 2011a. The Anthropocene: a new epoch of geological time? Phil. Trans. R. Soc. A 369(1938): 835-841.

Zalasiewicz J., Williams M., Fortey R., Smith A., Barry T.L., Coe A.L., Bown P.R., Rawson P.F., Gale A., Gibbard P., Gregory F.J., Hounslow M.W., Kerr A.C., Pearson P., Knox R., Powell J., Waters C., Marshall J., Oates M., Stone P. 2011b. Stratigraphy of the Anthropocene. Phil. Trans. R. Soc. A 369(1938): 1036-1055. .

Recebido 19 de dezembro de 2013 Aceito 15 de agosto de 2014 